\title{
PROBLEMS OF THE DEVELOPMENT OF ADMINISTRATIVE LAW AND ADMINISTRATIVE AND LEGAL DOCTRINE IN THE REPUBLIC OF ARMENIA (CONCEPT AND SUBJECT MATTER OF ADMINISTRATIVE LAW, ADMINISTRATIVE LAW WITHIN THE SYSTEM OF PUBLIC LAW, THE SYSTEM AND SCIENCE OF ADMINISTRATIVE LAW)
}

The author of this study has studied in details the problems of the formation and development of administrative law, administrative and procedure law, administration and administrative doctrine in the Republic of Armenia (Khandanian, 2019).

The relevance of the research. The integrated institution of systemic protection of individual rights and freedoms became a part of administrative and legal regulation's mechanism in the areas of administration and administrative procedure after the amendments to the Constitution of the Republic of Armenia (December 6, 2015), which established the legal protection of individual rights and freedoms as a priority (the Art. 3 and Chapter 2 of the Constitution of the Republic of Armenia).

The national science of administrative law at present time, is undergoing a rethinking, updating and replenishment of the conceptual apparatus. This process is associated with changes in the economic and legal systems of the Armenian society.

The tasks related to the formation of the civil society and legal state in Armenia make it necessary to take a fresh look at many administrative and legal concepts that have become customary with regard to their compliance with the modern stage of development of administrative law and the science of administrative law of the Republic of Armenia.

The theory of administrative law, which has the status of fundamental science in the system of national jurisprudence, faces complex challenges - revising and rethinking the scope of such fundamental concepts as legal personality issues in administrative law, as well as the concepts and content of administration, administrative and legal acts, the purpose and objectives of administrative procedure, etc.

Objective of the research. The objective of the research is to develop the basic provisions of the scientific concept of modern administrative law and procedure corresponding to what happened in Armenian society. Besides, the present study is aimed at a comprehensive, interrelated study of theoretical problems of administrative law and procedure in the context of the reforms carried out in our country, the transfer of legal theory and practice into a qualitatively new status.

Research method. The methodological basis of the research consists of the provisions of modern scientific methodology, the latest tools and methods of the theory of administrative law and other branches of law. While working on the topic the author has focused on the results of the research of national and international theorists and practitioners working in the areas of public administration and administrative procedure. The systematic approach to the problems of administrative law made it possible to conduct a thorough analysis of the attributes of administrative law and procedure. The author of the work has also used the methods of scientific cognition, logical methods of analysis, synthesis, generalization, comparison, abstraction. 
According to the author of the research, the analysis of any state and legal problem, including the problem of administrative law and procedure, should be carried out on the basis of the concept of the rule of law state.

The main results of the research. The implementation of the norms of administrative law in the modern period of the development of the Armenian society is one of the most urgent tasks of the state and legal activity. Administrative and legal norms are of paramount importance for the entire society in the and for each citizen of the Republic of Armenia in particular, through the regulatory acts of its agencies related to ensuring the rights and legitimate interests of citizens and economic entities in the field of public administration. The norms of administrative law play an important role in the regulation, organization and functioning of the state apparatus, ensuring the proper and timely definition of positive relations in the field of public administration through administrative procedures and regulations. In this regard, the author focuses on the key issues of political and legal modernization and improvement of administrative law and procedure of the Republic of Armenia. In particular, the author has revealed the content and characteristics of the subject matter of administrative law of the Republic of Armenia, the place of administrative law in the system of public law, the system and science of administrative law.

As a result of the work, carried out in accordance with the objective of the research, the author has come to certain results and conclusions that probably reflect the main tendencies in the development of administrative law and procedure of the Republic of Armenia and, in our opinion, will contribute to enrichment of the conceptual apparatus of the science of administrative law and procedure.

The improvement and amendments of Armenian legislation, the socio-economic and political reforms carried out in the Republic of Armenia, and the transformation of administrative apparatus have a significant influence on the science of administrative law.

According to the author of the research, it is almost impossible to find a sphere of public relations that would not be left without administrative and legal influence.

The author of the research has also paid attention to the problems of administrative procedure, administration, legality, administrative justice, correlation of administrative law, procedure, administration and the relevance of the problems of law-enforcement practice.

The research that we have carried out suggests that separation from the absolutization of the regulatory approach to administrative law prevailing in the Soviet legal science, diversity of opinions is in legal thinking and integration of legal sciences, the subject of which includes administrative law and procedure as objects of the research, in predetermining changes in the subject matter's content, system and structure of administrative law and procedure.

The systematic approach to study basic institutions of administrative law deepens our understanding of the social nature of administrative law and procedure, allows for a deeper study of individual institutions and categories of administrative target-oriented development of a civilized society.

Due to changes occurring in the country, the system and structure of administrative law and procedure, as well as formal sources of administrative law (for example, judicial and administrative precedent) also change.

The author of the research has highlighted the importance of creating an adequate philosophical, legal and ideological paradigm of the development of administrative legal awareness and worldview, ensuring legal stabilization of Armenian society in the context of modernization of the political system of the Republic of Armenia and declared reform, based on key principles of modern democratic law, respect and protection of human rights and freedoms. 
Conclusions. The following conclusion, formed in the work, is that the doctrinal understanding of administrative jurisprudence is, to say the least, inconsistent; this is the main problem of the theory of administrative law, which, in the author's opinion, can be removed by reforming legislation (for example, with the adoption of the new Code on Administrative Offenses, etc.).

According to the author, it can be stated that the importance of administrative and administrative procedural legislation, as well as the norms of administrative law in general, attracted and attracts the attention of scholars and practitioners. Considering the current tendency in the development of legal science, it can be argued that the science of administrative law will continue to develop intensively and perspectively in the future.

Key words: legal state, reform, administrative law, administrative procedure, modernized society, law system, law and order, state authorities, civil society, jurisprudence, political system, human rights, administration, administrative act, law-enforcement practice, interpretation. 


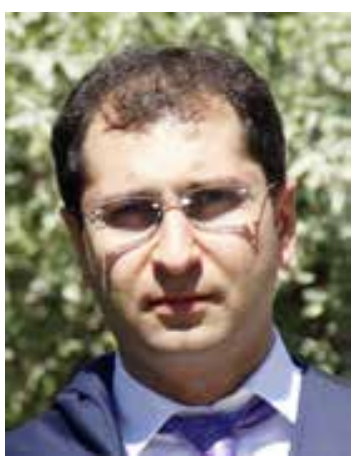

Rafik Khandanian, Judge of Administrative Court of the Republic of Armenia, Senior Lecturer of Constitutional and Municipal Law Department of Russian-Armenian University, Postdoctoral Student of Russian-Armenian University, PhD in Law orcid.org/0000-0001-7543-8793 rkhandanyan@yandex.ru

\section{Introduction}

The legal system of the Republic of Armenia has entered a completely new stage of legal and political developments, which is characterized as an ambitious initiative to form legislation inherent in a sovereign state's legislation and corresponding law-enforcement experience (Republic of Armenia 25 th anniversary, 2017). The state policy administering consonant with building statehood was announced in our country with the acquisition of state independence, that meets modern international criteria and solely dictated by the principles of democracy and universal human values.

Inevitably, these really necessary and fair intentions faced a number of obstacles, among which we also feel the lack of sufficient grounds and conditions for the required professional skills. Moreover, the creation of a really unique system of national law could not be considered realistic in a fundamentally reformed society and in the context of the main tasks in overcoming the various challenges facing the latter in the shortest time, and ultimately, taking adequate steps towards the formation of legal political culture with a democratic spirit.

With the adoption of the new Law of the Republic of Armenia "On the Fundamentals of Administration and Administrative Proceedings" on February 18, 2004 (Parliament of the Republic of Armenia, 2004) and "Administrative Procedural Code" on January 7, 2014 (Parliament of the Republic of Armenia, 2013), Armenia has taken a decisive step in the field of administrative law and the establishment of a legal state. Although the basis for this was already laid in the new Constitution, adopted in 1995, however, to implement these principles, it was necessary to abandon the old Soviet laws, the starting point of which was the dominant position of the state over private individuals. Administrative law of the Soviet era did not protect citizens before the state, but was aimed at guiding the behavior of citizens through sanctions.

This process of changes was also characterized by the introduction of new structures, structures and methods of research. This turn of common administrative law leads the Armenian people to the adoption of the constitutional and administrative traditions of Europe. It is characteristic for these spiritual and political traditions that state power and its holders are constrained by law, that law is higher than power and that political power can act exclusively within the framework of law. Thus, Armenia joins the highest criteria of the European legal culture that dominates in the countries of the Council of Europe. 


\section{The concept and subject matter of administrative law}

The key to the implementation of the policy of the government of the Republic of Armenia in the current era of social development, consonant with the key tasks of the fundamental revision of legal and political views in regard to the relationship between the state and individuals regarding these topical phenomena and legal institutions, is scientific and practical preparation of adequate depth and awareness in line with international legal criteria.

It is extremely easy to talk about the need to overcome the Soviet mentality, as well as about fundamental revision of the Soviet legal political system and its movement to a democratic basis, but in practice the steps that are taken in this direction can be profound and fundamental only when we properly understand and we perceive the essence of these mutually opposing systems with the criteria of professionalism, their positive and negative sides, expected difficulties and effective ways of overcoming them and the ways to mitigate the serious consequences of the inevitable collision of the old and the new, etc. Any attempts to deny any institution and component of the old legal system and the inability to find a replacement distort public perceptions about democratic institutions, resulting in undisguised mistrust in the society's legal awareness even to indisputable democratic principles and nostalgia for the past.

In the basis of the full-fledged formation of legal statehood, the implementation of state power in the present era, in the context of proclaiming a person, his dignity, fundamental rights and freedoms as supreme values, we inevitably feel the need not only for legal, organizational, political or economic guarantees, and for the desired legal culture, the direct path of which is legal knowledge and practical skills (Zelentsov, 2015: 11-12).

Thus, the administration realized by the competent authorities of the state plays a crucial role in the process of forming people's attitude towards the state and statehood. Each person in an incomparably greater extent and framework is associated with the agencies realizing the administration than with the agencies vested with the competence of the legislative or judicial power and their officials, which also emphasizes the important social meaning of administration. Among the effective guarantees of administration that are consonant with the principles of democracy is the availability of sound administrative legislation and adequate knowledge of administrative law.

Unlike other branches of law, administrative law is distinguished by an incomparably wide range of legal grounds, as well as by the institutions they establish. If the legal norms of some branches of law are consolidated mainly in one fundamental legislative act, the other branches of administrative law are extremely diverse and numerous.

To draw up an initial idea of administrative law, you must first distinguish its subject matter. The subject matter of administrative law - is "administration". It corresponds to the Latin noun "administratio" and the verb "administrare" and has several meanings: to serve, manage, guide, as a noun: administration, execution, realization, government, etc. (Gamzatov, 2002: 37-38).

\footnotetext{
${ }^{1}$ English administration - administrative law, French Administration - droit administrative, German Verwelung - Verwalungsteebt and others.
} 
The term "administration" is understood as the long-term implementation of the tasks of the executive power in any state. Thus, administration from ancient times was associated with political power, no matter what ideological orientation this power would have. Administration is a mandatory element of state power, and therefore is a universal phenomenon.

The modern state, which was originally appeared in Europe, at the dawn of the New Age, that is, approximately in the XVI century, serves as an example for all existing states today, the importance of administration is constantly growing. The main reason for this is that the state at present time is opposed to a person who takes an active responsibility for almost all spheres of public life and, thus, has almost everywhere taken over the powers. Initially these powers were limited to meeting the needs of the regular army - the main tool of an active foreign policy, as well as the protection of citizens' life, health and property, and the provision of security as they said at that time in Europe. Starting from the XVIII century, the state began to be actively engaged in economic, labor, transport, education, science, social welfare for the disabled and the elderly, health care, energy supply, and in the Modern time also in the protection of the environment.

Naturally, the subject matter of administrative law can only be public administration, that is, state administration and local self-government. Meanwhile, administration of private enterprises and organizations is not public administration.

In this regard, administrative law with its legal meaning acts as a managerial law or the law right of management. No wonder that, in general, administrative law is considered as the law to govern.

The concept of administration in laws and legal practice is used in two senses: administration in an organizational sense and administration in a functional sense.

In an organizational sense, administration includes all subjects: agencies, organizations and officials who carry out administrative activities and are called administration ${ }^{2}$. They together constitute the administration. Its typical representatives are administrative agencies (Danielian, 2012). As a part of the executive power, they differ from both the policy makers - the Prime Minister, the President and the Government of the Republic, and the courts, which are the agencies that administer justice.

In a functional sense, management is the activity of administrative agencies administration. Administration, in turn, can be viewed from two aspects - the formal and the material. From a formal point of view, speaking about management, we refer to the form of administration. A characteristic form of activity of administrative agencies is an administrative act ${ }^{3}$. The latter is a settlement carried out by an administrative agency or an official whose purpose is to regulate the behavior of certain legal entities specifically involved in this act. Consequently, an administrative act is concrete and individual regulation, in contrast to a normative legal act, which has the character of an abstract

\footnotetext{
${ }^{2}$ Despite the fact that the expression "administration" was used back in the years of the First Republic (1918-1920), it was most widely used in post-Soviet Armenia. In the Soviet period, the term "administration" was used instead of the term "administration".

${ }^{3}$ An administrative act is a decision, order, order or other individual legal act that has an external effect that the administrative body has adopted in order to settle a specific case in the field of public law and is aimed at restricting, changing, eliminating or recognizing the rights and obligations of persons.
} 
and general regulation. Classical examples of an administrative act are building permits issued by the head of the community, a license issued by the ministry, an order of a police officer to a person during the road trafficking, etc. The formal definition of an administrative act is given in Part 1 of the Art. 53 of the Law of the Republic of Armenia "On the Basis of Administration and Administrative Procedure" (Parliament of the Republic of Armenia, 2004) and it is not by chance that it occupies a key place in this law, the law that is the basis of the general administrative law of the Republic of Armenia.

From the material point of view, speaking about administration, the author emphasizes on an active and concrete modification in public relations, which is characteristic for administrative activity. It is true that this modification is made on the basis of laws, within their framework, therefore, its goals are also predetermined by law; however it is not limited to the purely mechanical execution of laws. Moreover, the activity of administrative agencies is characterized by a creative element. It is expressed in giving adequate legal solutions to specific situations, choosing the most suitable and effective means for this.

Through legal forms of administrative law, we ensure the most effective implementation of the original executive tasks and functions characteristic for the activities of state administration (executive power). Based on the interests of the state and citizens in the sphere of implementing the executive power, administrative law gives public and legal nature to administrative relations (Kostennikov et al., 2015: 10-12).

Thus, administrative law is one of the fundamental, most important branches of law and, along with constitutional, civil and criminal law, occupies a leading position in the sphere of regulating social relations.

Taking the aforementioned initial provisions as a basis, and also in order to adequately understand the subject matter of administrative law, one should imagine the real role of this branch of power, which was approved by the majority within the legal system of the Republic of Armenia:

1) administrative law exercises its regulatory influence in relation to such public relations with the participation of citizens, their associations and other various public associations that do not arise on their own or under the influence of other branches of power, but only under the influence of those relations whose emergence associated with state administration activities;

2) administrative law, as a manager of public relations, is directly manifested in the field of a special - state administration (executive power). The latter is connected with the provision of individual and group interests of citizens, as well as with the settlement of economic, socio-cultural, administrative and political processes. Without the participation of the executive authorities, their officials (special subjects of the executive power), these relations can not be counted among a number of objects of administrative law;

3 ) in the field of state administration, administrative law regulates those social relations that arise not only in connection with the implementation of their tasks and functions by the executive authorities and their officials (special subjects), but also on the basis of the fulfillment of these functions and the related powers in practice. Due to the latter features, these agencies and officials are considered as subjects of the executive power and are empowered with special authorities of the executor-manager nature; 
4) administrative law regulates such social relations, where the legal equality of its participants (parties) is fundamentally absent. This is due to the fact that an executive agency (an official), endowed with such powers that the other party does not have (participant), acts as an obligatory party within administrative and legal relations. This circumstance served as the basis for the will of the latter to be subordinated to the unilateral legally authoritative expression of the will of the said agency (an official);

5) the regulatory role of administrative law is often expressed in the framework of the norms of other branches of law. It is assumed that the relations that are included in the subject matter of other branches of law (labor, financial, etc.) can be administrative by their very nature (Kostennikov et al., 2015);

6) administrative law regulates relations arising in connection with cooperation between local self-government agencies not included in the system of state authorities and state agencies (officials). They are maximally expressed in cases when local self-government agencies are delegated to perform certain functions of government agencies. In this case, the subject of the executive power (state agency) within the relations regulated by administrative law, may be absent, however, the latter is replaced by a party equal in the legal sense - the local self-government agency and is endowed with the necessary amount of powers of a legally authoritative character. In this case, the local self-government agency acts on behalf of the state authority (Mikhailova, 2006: 846-847).

The study of the practice of the executive agencies and the characteristics of the participants in various managerial relations governed by administrative law gives grounds to distinguish the following most characteristic types:

1) between subjects of executive power and citizens;

2) between subjects of executive power and public associations;

3) between subjects of executive power and various state economic and socio-cultural associations, institutions, organizations;

4) between subjects of executive power and executive agencies of local self-government;

5) between subjects of executive power and state agencies, organizations subordinated to them;

6) between subjects of executive power at various levels (superior and subordinate, republican, territorial, sectoral, intersectoral, subordinate and non-subordinate, etc.);

7) between executive authorities and their employees;

8) between executive authorities of the Republic and international organizations, associations.

Among the participants of the above mentioned state-management relations, citizens have the most spread participation. Within the framework of these relations, executive authorities (officials) expand their activities in the direction of the realization of the rights, freedoms and duties of citizens in the field of state administration and the protection of their interests.

It should be also emphasized that administrative law among these relations does not regulate relations between citizens, as well as between public associations, since there is no special subject of executive power regulated by administrative law. This kind of relations is regulated by civil law. 
On the basis of the effectiveness of the legal impact of administrative law, it is necessary to clearly distinguish between the social relations that are characteristic for a particular branch of law or are adjacent to it and separate from them those special relations that are regulated by administrative law (Bakhrakh, 2010: 16-17).

Administrative law corresponding to the theory of law, unlike other branches of law, has two types of subject-object relations:

1) the so-called, exclusively legal relations, which constitute only the subject matter of administrative law and are fully regulated by it exhaustively (for example, the procedure for preparing and adopting administrative acts, administrative regimes, the status of executive agencies and the organization of labor, the legal status of employees of the apparatus, etc.);

2) the so-called adjacent relations, which constitute the subject matter of administrative law, but are often regulated by the norms of other branches of law (constitutional, financial, etc.). Relationships of this group are particularly numerous in administrative law, taking into account the most capacious framework of applying the latter. They are applied universally in a consistent manner or through the binding of common and detailed norms.

Some experts in the field of administrative law set out the definition of administrative law briefly, the rest - in volume (Kostennikov et al., 2015). This is due to the fact that state management relations are extremely changeable, as regards both in volume and applied spheres, as well as the content and methods of implementation. Besides, the institutional characteristic of administrative law, as well as in relation to the restructuring carried out in post-Soviet states and management reform processes, is influenced to a certain extent by the theory and practice of management in foreign countries. We should note some of them.

In our opinion, administrative law is a set of legal norms regulating social relations arising in the process of the organization and operation of executive power (state administration).

Administrative law, as has been noted, is an independent branch of the unified legal system of Armenia and regulates peculiar social relations. Being an integral part of the structure of the law of the Republic of Armenia, administrative law relates to it as part and whole. According to this principle, administrative law in its essence does not differ from other branches of law. This is due to the fact that both the norms of administrative law and the norms of other branches of the legal system are determined by an authorized state agency, they have a generally binding character and their execution is guaranteed by means of coercion.

However, it should be noted that administrative law differs from other branches of law in the subject matter and method of regulation. This feature lies in the fact that the branch of administrative law, taking into account the peculiarities of state administration activity, in its regulatory impact, unlike the other branches of law, covers a rather wide range of social relations that arise in economic, socio-cultural, administrative and political life of the country. In this regard, administrative and legal norms often penetrate into the areas of regulatory activity of other branches of law. The basis for such phenomena is essentially the presence of actual managerial relations in those branches of law that 
are subject to regulatory influence. This is how the diversity of forms of administrative and legal regulation is expressed.

These features predetermine the content and significance of administrative law as the branch of law. At the same time, it is necessary to take into account that there are also norms of other branches of law in the sphere of state regulation, which regulate emerged public relations not covered by administrative law, but those that have to be regulated by them.

Being a branch of fundamental law in the nature and being in close cooperation with other branches of law, they often serve as the basis for already established and existing or newly created branches of law (for example, financial, environmental, customs, tax, official, etc.).

Consequently, as a rule, any branch of law under the present conditions does not exist without a close relationship with other branches of law, which is of great importance both for other branches of law and especially for the nature of administrative and legal regulation (Korenev, 1961: 21-22).

If certain branches of the legal system are considered relatively independent (for example, constitutional, civil, international, criminal) and regulate relations of a clear range, then administrative law does not have such limited strict boundaries. Therefore, there is no such peculiar issue at present time that could be considered purely administrative, since it also affects the interests of the remaining branches of the system of the single law of the Republic. There are also such branches of law, in particular, financial, land, water, where the interaction of political and legal, criminal and legal, administrative and legal norms is expressed.

Reforms of state institutions carried out in the Republic (Danielian, 2011), as well as a sharp decline in the state sector due to privatization, as a result of which various objects remained outside the influence of the direct control of state administration, does not imply that they also remained outside the framework of administrative and legal regulatory relations. The forms and methods of realizing state administration have just changed (Khandanian, 2017).

The range of administrative and legal norms and the number of administrative regulations also did not decrease because of the aforementioned reasons. On the contrary, the number of such legal acts has increased. This is particularly noticeable in the sphere of solving human rights problems (for example, about six dozen amendments and alterations to the Code of Administrative Offenses of 1993-2018, the Law of the Republic of Armenia "On the Basics of Administration and Administrative Procedure" and other administrative and legal acts). Administrative law in this context also acts as a regulator of social relations of other branches. Thus, administrative and legal regulatory norms are used to ensure environmental, labor, tax, customs and other relations (for example, certain powers are established, exercising control in various areas of the agencies, organizational principles of entrepreneurial activity, the procedure for accepting and terminating public service, collecting taxes and duties, as well as state control over their observance, etc.).

One of the characteristic features of administrative law is also the relationship with the definite branches of the legal system of the Republic of Armenia. The legal system consists of such branches of law, which are primarily distinguished by the subject matter and method of legal regulation. Moreover, the subject matter of each branch of law is those social relations that are regulated by the norms of this branch (Siniukov, 2010: 25-26). 
Administrative law, as a branch of law, is regulated by a set of special social relations that arise in the process of state regulation, that is, the organization of their activities of the executive power system. More specifically, these are relations arising in connection with intraorganizational administrative activities on the part of the heads of a number of organizations and state administration agencies. In this kind of managerial relations, state interests and the managerial will of the state are directly reflected. Public relations of precisely this nature are usually called managerial, which constitute the subject matter of administrative law.

Thus, the subject matter of administrative law covers two groups of social relations of a managerial nature: a) relations directly related to the implementation of state administration (executive power) (main group) and b) other, in particular, intraorganizational relations arising in the course of the activities of other state agencies (auxiliary group).

In other words, the subject matter of administrative law is constituted by such management relations that arise, change and are terminated in connection with the implementation of executive power (Khandanian, 2018b).

However, it must be borne in mind that not all public relations with the participation of executive authorities are included in the subject matter of administrative law. For example, if any executive agency, in accordance with the procedure established by the Civil Code, acquires property, such a transaction is not an action for the implementation of the executive power.

At the same time, it is necessary to take into account that not all managerial public relations can be subject matter to administrative law. This is due to the fact that management activities are carried out not only by state agencies, but also by various non-state formations (for example, public associations, commercial organizations, etc.). Although the relations of these non-state formations are managerial in nature, they mainly reflect the interests and will of the members of the respective organization and are connected with the organization (self-organization) of their own affairs. The latter, as subjects of administrative law, do not act on behalf of the state and do not reflect its interests. In spite of the fact that the state formations are obliged to obey the general legal regime established in the field of state administration.

The subject matter of administrative law also covers such diverse relations that sometimes act in the norms of other branches of law (labor, financial, environmental, business, etc.). For example, the powers of the executive branch ensure the rule of law in these branches, the organization of natural resource management, etc.

The subject matter of administrative law also includes those issues of administrative and legal regulation that arise from public relations, regulated not only by management, but also by other branches of law (Atamanchuk, 2003: 27-28). In such cases, the specific feature of administrative law is expressed in the fact that it has legal means at its disposal, in the form of administrative liability, to protect these relations.

Administrative influence of administrative law extends to organizational and legal relations, which arise in particular in the field of activities of other branches of power (for example, the National Assembly, in the process of organizing the work of the judiciary). This kind of relationship is subject matter of administrative law. 
Management relations arising in the field of activity of local self-government agencies are also included in the subject matter of administrative law.

Thus, the main types of administrative relations that are directly related to the state administration, that is, the implementation of the executive power, are related to the subject matter of administrative law.

\section{Administrative law within the system of public law}

The legal system of the Republic of Armenia is part of the European continental legal system. This system, called "Romano-Germanic" from a structural point of view, differs significantly from the Anglo-Saxon (common law), where large parts of civil law are not codified, but developed by the courts, that is, on the basis of judicial acts (precedents). Therefore, in the "common law" countries (the USA, Great Britain, Canada, India, Australia, South Africa, etc.), the courts as the "third power" in the states, play a greater role than in countries of continental law.

Meanwhile, the law is subject to codification in the countries of the European continental legal system (from the Latin word codex, which means "code") in the form of laws that are adopted as a result of democratic elections by organized and authorized parliaments by the constitution to adopt laws. Therefore, the legislator plays a decisive role in the legal system of these countries 4 . He also "programs" the administration of justice through laws, because the courts are subordinate to the law.

The roots of the European continental legal system are in Roman law. It is the origin for the crucial division of the entire (national) legal system into two major legal branches: private and public law. Civil law constitutes the most important part of private law. Administrative law is a part of public law.

This distinction has not only scientific, but also practical importance. Scientifically, it helps us to see more precisely and, therefore, better understand the structure of the legal system and the characteristics of its components. This, in turn, has a positive effect on the interpretation and application of laws and their individual provisions. And in practical terms, this distinction is important, since the norms of private law, as a rule, are applied in a different way and in other processes, the norms of public law. This is also the case in the Republic of Armenia, since public and legal disputes that have administrative and legal nature are resolved by administrative courts and the court of cassation (the Chamber on Civil and Administrative Cases) 5 .

In order to find out whether this or that legal norm is applied to the sphere of public or private law, there are various theoretical approaches and criteria that have been developed in jurisprudence. For Roman lawyers, it was crucial whose interests this legal

\footnotetext{
${ }^{4}$ Nevertheless, the power of the legislator, as a rule, is more limited in those countries where there is a constitutional court, which by its decisive interpretation of the constitution in some cases establishes that certain laws are unconstitutional, declares them invalid and thereby ensures the subordination of the parliament (legislator) provisions of the constitution. Such is the situation in the Republic of Armenia, the Constitution of which provided for the existence of a constitutional court and assigned to it also the competence to establish the constitutionality of legal acts (Articles 167-170 of the Constitution of the Republic of Armenia).

${ }^{5}$ The provisions of the Judicial Code of the Republic of Armenia, adopted in 2018, in combination with Articles 1 and 3 of the Administrative Procedure Code of the Republic of Armenia, adopted on December 5, 2013.
} 
norm serves. If it served the public interest and thereby prospering the society (Latin res publica $=$ public business $=$ state), then it was a public right (ius publicum), and if it served individuals, it was a private right (ius privatum).

Based on the principle of the division of the rule of law into two major parts, the sphere of public law includes constitutional, administrative law, judicial law, criminal law and all procedural codes. Meanwhile, the category of public law is perceived, as a rule, in legal faculties and in legal practice, in a narrower sense, namely, as a general concept, which includes constitutional law, administrative law. The fact is that criminal law, along with criminal procedural law, the law relating to the prosecutor's office, penal law, criminology and criminalistics is a large, interconnected and very specific complex. Due to the close intertwining of material, civil, and economic law, public law should also include civil procedural law - as a related branch (Khandanian, 2018a).

For the same reason, constitutional procedural law and administrative procedural law are included in public law.

Thus, public law in the narrow sense includes constitutional law, state law and administrative law, as well as derived from them constitutional procedural and administrative procedural laws.

At the same time, the matters that constitute the core of public law constitute one system, since they are closely interconnected due to common structural principles. Constitutional law, state law and administrative law are hierarchically related to each other. This relationship can be represented in the form of a pyramid.

The top of the pyramid of the legal system of the Republic of Armenia is the constitutional law. It is a set of provisions contained in the Constitution of the Republic of Armenia, adopted on July 5, $1995^{6}$.

Constitutional law is a set of legal provisions relating to two large groups: the system of state agencies and the fundamental rights of citizens (Mikhailova, 2006: 15-17). The rights regulating the system of state agencies combine provisions on the legal status of supreme state agencies, the Prime Minister, the President of the Republic, the National Assembly, the Government, the Constitutional Court, their organizational structure, their formation, functions and powers, as well as their relations. They are supplemented by legal provisions on the legal status of an individual, that is, on the rights of a man and a citizen and obligations of a citizen, and legal provisions on the fundamentals of civil society inseparably linked to them, that is, on political parties, public organizations (non-governmental organizations sector), mass media, etc.

Administrative law is next lower order than the constitutional and state law. It is the bottom step - the basement of the pyramid of the public law system. It can be defined as a set of provisions regulating the organization and activities of administrative agencies and officials, that is, all those subjects of public law that are neither the parliament, nor courts, nor government. Administrative law, divided into general and special parts is the largest, voluminous part of public law.

\section{The system and science of administrative law}

Administrative law, regulating social relations of a wide range, acts as a branch of law, as a branch of legal science and as a training course. If administrative law, as a system

\footnotetext{
${ }^{6}$ The Constitution of the Republic of Armenia was amended through referenda of 2005 and 2015.
} 
of interrelated legal norms, dictates proper behavior, then the science of administrative law studies, classifies and coordinates these norms, unites them according to legal institutions and represents them in a particular system.

Being a sphere of human activity, the science of administrative law, as a legal science, studies, explains administrative and legal phenomena through specialists. The science of the branch also covers knowledge of the accumulated and systematized norms of administrative law, institutions, concepts and categories, with the aim of developing which and providing weighted information using appropriate methodological tools. These tools are the composition (content) of administrative law science, which also includes the subject matter, method and system of science, scientific terminology, category (type) of science, as well as the sectoral bibliography and history of science. At the same time, the basis of this composition is the subject, method and system of science.

There are different opinions in the issue of the characteristics of the subject matter of administrative law science.

In our opinion, the science of administrative law is a system of scientific points of view and ideas, knowledge and theoretical provisions on administrative law and the subject matter of its regulation.

Most scholars argue that the subject matter of administrative law science is the current administrative law (Lapina, 2009; Chetverikov, 2004). However, according to administrative law, the latter has its constituent parts: administrative and legal norms, administrative and legal categories and the application of administrative law norms.

The norms of administrative law are coordinated and united into institutions, subbranches and are systematized. Administrative and legal relations arising from these norms, their parties (participants), legal facts, material and procedural, internal organizational and external organizational issues are also studied.

Knowledge on the norms of administrative law is important (Borodin, Gromyko, 2007: 41-42). Only knowledge of the current administrative law can not provide adequate knowledge regarding the legal regulation of social relations in the field of executive power (state administration). This knowledge includes such categories as "executive power" (state administration), "executive authorities" (state administration agencies), "public service", "officials", "administrative coercion", etc. The above categories reflect the essential characterizing this branch of the legal system and the issues of organization and development of which are directly influenced by the subject matter of the science of administrative law.

One of the important components of the subject matter of administrative law science is the practice of state administration, as well as law enforcement activity of the executive authorities (state administration), and their officials. The science of administrative law studies administrative and legal norms and the practice of their application both with management agencies (officials), and with citizens and interested organizations. The study of practical implementation of administrative and legal norms provides an opportunity for the science of administrative law to submit scientifically grounded propositions to the competent authorities (officials) on structural changes to improve the efficiency, change, supplement or eliminate relevant administrative law norms, or make structural changes to improve efficiency of the competent authorities' activities (Kostennikov et al., 2015: 121-133). 
Thus, the subject matter of the science of administrative law is the study and analysis of practical implementation of social relations arising in this area of executive power (state administration) and regulating their administrative and legal norms, as well as the identification and study of general and characteristic patterns of administrative and legal regulation of social relations.

The main legal institutions of administrative law and the science of administrative law of the Republic of Armenia fundamentally correspond to each other; however, in general, the system of science of the branch has some characteristic features:

1) it contains complete knowledge on administrative law and its institutions, as well as on general concepts of the branch (for example, the principles of the subject matter and method, administrative and legal norms and relations);

2) non-integrated and mixed materials are systematized into logically formed administrative and legal institutions, which makes it easier to inform about them, their use and influence on the system of administrative and legal norm;

3) summarizes the data related to the structural, sectoral and procedural system of administrative law into a single system of knowledge on administrative law.

The system of science of administrative law in the whole must contain any kind of knowledge on administrative and legal institutions and on administrative law in general.

Political and economic reforms carried out in the Republic, the application of the principles of democracy and other processes in relation to the executive power (state administration) created an objective need for a new discussion of the concept and subject matter of administrative law, skillfully using previously developed sustainable scientific research and experience of foreign countries. Undoubtedly, these changes will continue to be made, considering the constitutional division, improvement and development of state authorities, the strengthening of a democratic, social, legal state, as well as a change in the forms and methods of government, its theory and practice. In regard to these processes, the legal system of the Republic will be significantly updated and reformed, including administrative law.

One of the important processes for the science of administrative law in the transition period is the revision of the problem of state regulation of the economy (Alekhin et al., 2003: 111-112). The transition from a single production and economic complex, that is, from a planned system to various economic relations, caused serious problems. The legal basis for the transition to market economy has not been fully studied yet. Absolute power methods in relation to previously existing economy were replaced by softer and more flexible methods in relation to objects of management. Besides, indirect managerial influence is applied in relation to the economy.

In terms of the implementation of market relations in the Republic, the problem of state administration seems to have become meaningless. It creates the illusion that improving the relations of the Republic with some countries and the assistance provided will mechanically contribute to the normal course of reforms.

Practical life also demonstrates that the creation, reorganization, liquidation of new agencies, ostensibly to increase the efficiency of the executive authorities (state administration), increase or decrease in their number, personnel changes, and the appointment of their leaders on a purely party basis, do not give the desired result. 
Meanwhile, new scientific approaches to management can become a real driving force for the development of society, if it is managed by professionals who possess adequate managerial knowledge and skills, resourceful, having a good knowledge of moral and global production and management experience. We think it would be appropriate to recall the idea of Democritus that the welfare of citizens of the state depends on the quality of management.

Nowadays, state administration should objectively reflect the need for effective management of economic, social, administrative, legal and other spheres and the use of the latest information technologies, which has visible advantages according to the experience of developed countries (Salomatin, 2013: 7-9). In this regard, the functional and managerial role of administrative law will be increased in the nearest future, and it is intended to perform the following main functions: a) organization and implementation of state administration; b) state administration; c) protection of public interests; d) implementation of citizens' rights to participate in state administration and local self-government.

The functions carried out in the field of state administration can, without hesitation, make more democratic, in particular, the publication of draft laws and other legal acts and public discussions, so that individuals and legal entities, whose interests are affected, can have an opportunity to announce their opinion on projects, as well as accessibility of adopted legal acts. Considering public opinion is one of the fundamental principles of law-making activity, which also contributes to the development of administrative legal awareness of the population and the creation of powerful levers in the law-making and law-enforcement fields.

The organization of state activity is directly related to public servants, who play an important role in solving problems of the economic, socio-cultural, administrative and political branches. Despite the fact that laws related to various public services have been adopted and are in force in the Republic, however, there are various kinds of problems in the process of their practical implementation, some of which are the gaps of the legislation and the rest - of practitioners (Egian, 2004: 89-90). At the same time, it should be noted that the basic principles of these services, the procedures for taking vacant positions, certification, retraining, the legal situation of community servants and other provisions do not significantly differ from each other. It is also strange that the special republican agency represented by the council of the civil service was created in the system of public service only in the sphere of the civil service. Service relations in all other public services are regulated in the manner established by the government or an authorized agency of the Republic of Armenia. We also consider that it is advisable to create a single republican independent public service agency in order to conduct a unified state policy in various public services, their leadership and organization.

Due to the weakening of the levers of state administration, the insecurity of citizens, legal entities from offenses and the arbitrariness of the apparatus has increased. Their protection is supposed to exercise law enforcement agencies and especially the administrative court (Danielian, 2002). By the way, the observance of public order and public security is closely related to the public economic order and this (business activities, development of various kinds of property, etc.) is possible if a strong public order and security is ensured. 
Despite adopted in 1985 and the current Law of the Republic of Armenia "On Administrative Offenses", numerous amendments and additions have been made, nevertheless, it is in a deplorable state. The improvement and development of administrative legislation is too slow and, sometimes, with conflicting decisions. This is also due to the fact that reforms on legal issues do not provide the concept of development of administrative legislation. Administrative and legal norms: the sources of administrative law, regulating various social relations, as compared with other branches of the law system of the Republic of Armenia, are in a chaotic state.

I believe that the further development and improvement of the legislation on administrative liability should take place on the principle of incorporating all legal norms establishing administrative offenses into one legislative act (code). Currently, it consists of the said code and numerous laws that are in parallel with it, which are not properly coordinated and lead to some contradictions, disagreements, comments and difficulties. In this regard, it is necessary to create a clear systematization of these acts, through the incorporation (unification) or mutual agreement and systematization of the latter. There is a need to expose administrative and legal acts to a proper codification.

Studying the legal systems of different countries is also important for the development of the science of administrative law of the Republic of Armenia. We should note that there is a convergence of legal systems of different countries and comparative law has a wider nature (Gevorgian, 2019). However, some features of management, administrative legislation of different countries are sometimes copied mechanically with distortions, taking into account the fact that they can not correspond to the processes, requirements, general situation, as well as internal patterns of administrative sphere. As a result, they create some difficulties in practice and the process of infinite amendments begins.

Generally, they are problems of consciousness of administrative law in the Republic in the future, which are relevant and interrelated.

\section{Conclusions}

The legal system of modern states, as a rule, differentiates the law of substance and formal law. The general doctrine of law understands the law of substance as the totality of legal norms defining the content of the rights and obligations of legal entities. In contrast, the formal law is understood as legal norms regulating the procedures, which assist to clarify the content of undefined right or the right under question and carried out despite possible resistance. The interaction between the law of substance and formal law can be demonstrated by the example of the Civil Code of the Republic of Armenia and the Civil Procedural Code of the Republic of Armenia. The Civil Code, in particular, establishes those rights and obligations enjoyed by the parties to purchase agreement, that is, the buyer and the seller. The duty of the seller and owner of goods is to transfer the goods to the buyer, and the buyer's obligation is to pay the agreed price and accept the goods (the law of substance). The Articles of the Civil Procedural Code regulate the process, where the parties to the purchase agreement, by applying to a (state) court of general jurisdiction, can force to recognize and exercise their (private) rights (requirements). Besides, if the debtor does not fulfill his duties approved by the court, the creditor's right is exercised in another proceeding with the help of a compulsory executor - within the proceeding of enforcement. The norms of procedural proceedings and enforcement are called formal law, in contrast to the law of substance. 
As soon as (the law of substance) civil law (private law) and the formal procedural law (public law) are related to each other, this relationship does not differ from that one, which exists between, on the one hand, substantive administrative law, and, on the other hand, the law regulating (formal) administrative proceedings and forced (formal) execution in the sphere of administrative law.

For (substantive) administrative law, that is, for the realization of the rights and obligations of citizens, business enterprises, public organizations (NGOs, etc.), the law regulating administrative proceedings is of primary importance. It is aimed at the adoption of an administrative act by an administrative agency, through which the substantive rights and obligations of individuals and legal entities are established on the basis of certain administrative and legal provisions. So, in contrast to administrative proceedings, a dispute on any substantive law within administrative procedure that takes place in an administrative agency is decided not by a sentence, but mainly by an administrative act that only recognizes the existence of such a right. Consequently, the main purpose of the law regulating administrative procedure is to strengthen its role in comparison with the state (administrative agency) by granting procedural rights to the non-state, private party, and thereby to reduce the power difference in favor of a citizen, and to provide an approximate balance between an administrative agency and a citizen by forming administrative and legal relations in the spirit of the rule of law.

The same goal was pursued by the creation of the specialized administrative court and the development and adoption of the Special Administrative Procedural Code. The fact is that the court and the judge, by specializing in administrative law, are able to better evaluate the activities of administrative agencies and officials, according to the laws, better control it and, thereby, ultimately, strengthen the legal status of a citizen in the realization of his legitimate interests and rights in a legal dispute with an administrative agency (state).

The logical complement and completion of formal administrative law is administrative justice. With the adoption of the "Administrative Procedural Code of the Republic of Armenia" (entered into force on January 1, 2008), the administrative court began to operate, which resolves administrative and legal disputes arising between individuals and/or legal entities and government authorities and/or local self-government agencies. Proceeding within administrative courts is carried out on the basis of the Administrative Procedural Code of the Republic of Armenia, which sets out in details the disputes considered by the administrative court. They can be summarized in three groups, first, cases that are initiated on the basis of a statement of private persons against administrative agencies or officials, secondly, cases that are initiated against private persons on the basis of a claim of administrative agencies or officials and thirdly, disputes between government authorities, local self-government agencies and officials. Usually citizens and economic entities file lawsuits against administrative agencies, that is, the administrative court most often investigates administrative and legal disputes of the first category.

By means of a claim, it is possible to oppose any kind of behavior and all types of actions of administrative agencies and officials, namely:

1) the adoption of administrative acts, but also to refrain from their adoption;

2) the adoption of regulatory acts; 
3) implementation of real actions, for example, blocking the road leading to the citizen's house, or refraining from real actions requested by the citizen, for example, from paying a certain sum of money.

In order to consider a lawsuit submitted to administrative court as admissible, it is necessary that administrative agencies or officials in all cases violated the rights or freedoms belonging to the claimant by their decisions, actions or omission. You can file a lawsuit in court in the case, when the claimant only "holds the opinion" that the administrative agency violated his rights. And whether the claimant's statement is true, is established by the administrative court, if necessary, through the acquisition of evidence.

The law regulating administration and administrative procedural law are such achievements of the rule of law state that are worthy of being considered "historical". They give a citizen more value in relation to the state in communicating with the authorities of the latter. These two examples should prevent the administrative authority, because of the mentioned, to treat individuals as objects and not to take into account their legitimate interests. According to the historical experience, they continue to exert influence in the future. Administrative law, consonant with the new - the legal state of Armenia, is able to overcome the past authoritarian style of administration.

Administration, administrative court and administrative procedural law are legal institutions that are especially closely related to the rule of law principle, namely within the context of the art. 1 of the Constitution of the Republic of Armenia. Consequently, these institutions make an important contribution to ensuring that the executive branch is constrained by the law. Thus, there are necessary legal prerequisites to avoid the danger of arbitrariness in the activities of the executive branch.

\section{Bibliography:}

1. Административное право / Г.В. Атаманчук, Н.М. Казанцев и др. ; под ред. Г.В. Атаманчука. Москва : РАГС, 2003. 391 с.

2. Актуальные проблемы административного права и процесса / М.В. Костенников, А.В. Куракин, А.М. Кононов, П.И. Кононов, А.И. Стахов, Н.Д. Эриашвили. 2-е изд., перераб. и доп. Москва : ЮНИТИ-ДАНА, 2015. 496 с.

3. Алехин А.П., Кармолицкий А.А., Козлов Ю.М. Административное право Российской Федерации : учебник. Москва : Зерцало-М, 2003. 608 с.

4. Бахрах Д.Н. Административное право России : учебник. Москва : Эксмо, 2010. 607 с.

5. Бородин С.С., Громыко С.С. Административное право. Общая и Особенная часть : курс лекций. Санкт-Петербург : ГУАП, 2007. 432 с.

6. Гамзатов М. Латинско-русский словарь юридических терминов и выражений для специалистов и переводчиков английского языка. Санкт-Петербург : Санкт-Петербургский университет, 2002. $508 \mathrm{c}$.

7. Геворгян В. Сравнительное правоведение : учебное пособие. Ереван, 2019. 300 c. (на армянском языке).

8. Даниелян Г. Административное право Республики Армения. Ереван, 2012. 400 с. (на армянском языке).

9. Даниелян Г. Административное производство и процесс. Ереван, 2011. 368 с. (на армянском языке).

10. Даниелян Г. Отрицательные последствия неведения института административной юстиции. Ереван. 2002. № 8 (46). С. 10-13 (на армянском языке). 
11. Егян Р. Гражданская (государственная) служба в Республике Армения. Ереван, 2004. 240 с. (на армянском языке).

12. Зеленцов А.Б. Административная юстиция. Общая часть. Теория судебного административного права. Москва : ЮНИТИ-ДАНА, 2015. 399 с.

13. Кодекс административного судопроизводства Республики Армения : Закон Республики Армения от 28 декабря 2013 г. № ЗР-139 / Парламент Республики Армения. Официальныле ведомости Республики Армения. 2013. № 73(1013). Ст. 1186.1 (на армянском языке).

14. Конституционное право России : учебник / под ред. Н.А. Михайловой. Москва : Эксмо, 2006. 900 с.

15. Коренев А.П. Кодификация советского административного права : дис. ... канд. юрид. наук. Ленинград, 1961. 200 с.

16. Лапина М.А. Административное право : курс лекций. Москва : Консультант Плюс, 2009. $149 \mathrm{c}$.

17. Об основах администрирования и административном производстве : Закон Республики Армения от 16 марта 2004 г. № 3Р-41 / Парламент Республики Армения. Официальные ведомости Республики Армения. 2004. № 18(317). Ст. 413 (на армянском языке).

18. Республике Армения 25 лет : сборник научных докладов. Ереван : Наука, 2017. 220 с. (на армянском языке).

19. Саломатин А.Ю. Всемирная история государства и государственного управления : учебное пособие. Москва : Норма, 2013. 288 с.

20. Синюков В.Н. Российская правовая система. 2-е изд., доп. Москва : Норма, 2010. $672 \mathrm{c}$.

21. Ханданян Р. Административное право Республики Армения : учебно-методическое пособие. Ереван : Изд-во РАУ, 2019. 350 с. (на армянском языке).

22. Ханданян Р. О переходном правосудии: теоретические подходы и обоснования. Судебная власть. 2018. № 7/8. С. 11-16 (на армянском языке).

23. Ханданян Р. Парадигма административного правосудия в современной юриспруденции. Судебная власть. 2018. № 9/10. С. 42-47 (на армянском языке).

24. Ханданян Р. Судебный контроль в контексте верховенства права. Законность. 2017. № 100. С. 37-42 (на армянском языке).

25. Четвериков В.С. Административное право России. Ростов-на-Дону : Феникс, 2004. $512 \mathrm{c}$

\section{References:}

1. Atamanchuk, G.V. (ed.) (2003). Administrativnoe pravo [Administrative law]. Moscow: RAGS [in Russian].

2. Kostennikov, M.V., Kurakin, A.V., Kononov, A.M., Kononov, P.I., Stakhov, A.I., Eriashvili, N.D. (2015). Aktualnye problemy administrativnogo prava i protsessa [Actual problems of administrative law and process]. Moscow: IUNITI-DANA [in Russian].

3. Alekhin, A.P., Karmolitskii, A.A., Kozlov, Iu.M. (2003). Administrativnoe pravo Rossiiskoi Federatsii: uchebnik [Administrative law of the Russian Federation: textbook]. Moscow: Zertsalo-M [in Russian].

4. Bakhrakh, D.N. (2010). Administrativnoe pravo Rossii: uchebnik [Administrative law of Russia: textbook]. Moscow: Eksmo [in Russian].

5. Borodin, S.S., Gromyko, S.S. (2007). Administrativnoe pravo. Obshchaia i Osobennaia chast: kurs lektsii [Administrative law. General and Special part: lecture course]. Saint Petersburg: GUAP [in Russian]. 
6. Gamzatov, M. (2002). Latinsko-russkii slovar iuridicheskikh terminov i vyrazhenii dlia spetsialistov i perevodchikov angliiskogo iazyka [Latin-Russian dictionary of legal terms and expressions for specialists and translators of the English language]. Saint Petersburg: Sankt-Peterburgskii universitet [in Russian].

7. Gevorgian, V. (2019). Sravnitelnoe pravovedenie: uchebnoe posobie [Comparative law: a study guide]. Yerevan [in Armenian].

8. Danielian, G. (2012). Administrativnoe pravo Respubliki Armeniia [Administrative Law of the Republic of Armenia]. Yerevan [in Armenian].

9. Danielian, G. (2011). Administrativnoe proizvodstvo i protsess [Administrative procedure and process]. Yerevan [in Armenian].

10. Danielian, G. (2002). Otritsatelnye posledstviia nevedeniia instituta administrativnoi iustitsii [Negative consequences of ignorance of the institute of administrative justice]. Erevan, no. 8(46), pp. 10-13 [in Armenian].

11. Egian, R. (2004). Grazhdanskaia (gosudarstvennaia) sluzhba v Respublike Armeniia [Civil (state) service in the Republic of Armenia]. Yerevan [in Armenian].

12. Zelentsov, A.B. (2015). Administrativnaia iustitsiia. Obshchaia chast. Teoriia sudebnogo administrativnogo prava [Administrative justice. General part. Theory of judicial administrative law]. Moscow: IUNITI-DANA [in Russian].

13. Parliament of the Republic of Armenia (2013). Kodeks administrativnogo sudoproizvodstva Respubliki Armeniia: Zakon Respubliki Armeniia ot 28 dekabria 2013 g. № 3P-139 [Code of Administrative Procedure of the Republic of Armenia: Law of the Republic of Armenia dated December 28, 2013 № 3P-139]. Ofitsialnye vedomosti Respubliki Armeniia, no. 73(1013), art. 1186.1 [in Armenian].

14. Mikhailova, N.A. (ed.) (2006). Konstitutsionnoe pravo Rossii: uchebnik [Constitutional law of Russia: a textbook]. Moscow: Eksmo [in Russian].

15. Korenev, A.P. (1961). Kodifikatsiia sovetskogo administrativnogo prava [Codification of Soviet administrative law] (Candidate's thesis). Leningrad [in Russian].

16. Lapina, M.A. (2009). Administrativnoe pravo: kurs lektsii [Administrative law: lecture course]. Moscow: Konsultant Plius [in Russian].

17. Parliament of the Republic of Armenia (2004). Ob osnovakh administrirovaniia i administrativnom proizvodstve: Zakon Respubliki Armeniia ot 16 marta 2004 g. № 3P-41 [On the basics of administration and administrative proceedings: Law of the Republic of Armenia dated March 16, 2004 № 3P-41]. Ofitsialnye vedomosti Respubliki Armeniia, no. 18(317), art. 413 [in Armenian].

18. (2017). Respublike Armeniia 25 let: sbornik nauchnykh dokladov [Republic of Armenia 25th anniversary: collection of scientific papers]. Yerevan: Nauka [in Armenian].

19. Salomatin, A.Iu. (2013). Vsemirnaia istoriia gosudarstva i gosudarstvennogo upravleniia: uchebnoe posobie [World history of government and public administration: a training manual]. Moscow: Norma [in Russian].

20. Siniukov, V.N. (2010). Rossiiskaia pravovaia sistema [Russian legal system]. 2nd ed., suppl. Moscow: Norma [in Russian].

21. Khandanian, R. (2019). Administrativnoe pravo Respubliki Armeniia: uchebno-metodicheskoe posobie [Administrative law of the Republic of Armenia: educational-methodical manual]. Yerevan: Izd-vo RAU [in Armenian]

22. Khandanian, R. (2018a). O perekhodnom pravosudii: teoreticheskie podkhody i obosnovaniia [On transitional justice: theoretical approaches and rationales]. Sudebnaia vlast, no. 7/8, pp. 11-16 [in Armenian]. 
23. Khandanian, R. (2018b). Paradigma administrativnogo pravosudiia v sovremennoi iurisprudentsii [The paradigm of administrative justice in modern jurisprudence]. Sudebnaia vlast, no. 9/10, pp. 42-47 [in Armenian].

24. Khandanian, R. (2017). Sudebnyi kontrol v kontekste verkhovenstva prava [Judicial review in the context of the rule of law]. Zakonnost, no. 100, pp. 37-42 [in Armenian].

25. Chetverikov, V.S. (2004). Administrativnoe pravo Rossii [Administrative law of Russia]. Rostov-on-Don: Feniks [in Russian].

\title{
ПРОБЛЕМИ РОЗВИТКУ АДМІНІСТРАТИВНОГО ПРАВА ТА АДМІНІСТРАТИВНО-ПРАВОВОЇ ДОКТРИНИ В РЕСПУБЛІЦІ ВІРМЕНІЯ (ПОНЯТТЯ Й ПРЕДМЕТ АДМІНІСТРАТИВНОГО ПРАВА, АДМІНІСТРАТИВНЕ ПРАВО В СИСТЕМІ ПУБЛІЧНОГО ПРАВА, СИСТЕМА ТА НАУКА АДМІНІСТРАТИВНОГО ПРАВА)
}

\author{
Рафік Ханданян, \\ суддя Адміністративного суду Республіки Вірменія, \\ старший викладач кафедри конституційного та муніципального права \\ Російсько-вірменського університету, \\ докторант Російсько-вірменського університету, \\ кандидат юридичних наук \\ orcid.org/0000-0001-7543-8793 \\ rkhandanyan@yandex.ru
}

У дослідженні докладно вивчаються проблеми становлення й розвитку адміністративного права, адміністративно-процесуального права, адміністрування та адміністративно-правової доктрини в Республіці Вірменія.

Актуальність дослідження. Зі змінами Конституції Республіки Вірменія, щзо відбулися б грудня 2015 р., було закріплено як пріоритет правової охорони права й свободи особистості (cm. $3 \mathrm{ma}$ глава 2 Конституції Республіки Вірменія). При иъьоу комплексний інститут системного захисту названих прав і свобод став частиною механізму адміністративного-правового регулювання також у сферах адміністрування та адміністративно-проиесуальної діяльності.

Нині вітчизняна наука адміністративного права переживає переосмислення, оновлення й поповнення власне понятійного апарату. Цей прочес пов'язаний зі змінами, щุо відбуваються в економічній і правовій системах вірменської громади.

Завдання, пов'язані з формуванням громадянського суспільства та правової держави у Вірменії, змушують по-новому поглянути на багато звичних адміністративно-правових понять щзодо предмета їх відповідності сучасному етапу розвитку адміністративного права та науки адміністративного права Республіки Вірменія.

Перед теорією адміністративного права, що має статус фундаментальної науки в системі вітчизняної юриспруденції, стоїть складне завдання - перегляд та переосмислення обсягу таких основоположних понять, якими є проблеми правосуб'єктності в адміністративному праві, а також поняття та змісту адміністрування, адміністративно-правових актів, мети й завдань адміністративного процесу тощз.

Мета дослідження полягає в розробленні основних положень наукової концепиії сучасного адміністративного права та процесу відповідно до подій у вірменському суспільстві. Крім того, робота націлена на комплексне, взаємозалежне дослідження теоретичних проблем 
адміністративного права й процесу в умовах здійснюваних у Вірменії реформ, переведення юридичної теорії та практики в якісно новий стан.

Методи дослідження. Методологічну основу дослідження становлять положення сучасної наукової методології, новітні засоби й методи теорії адміністративного права та інших галузей права. У роботі над темою акиент робиться на результатах досліджень вітчизняних та зарубіжнх теоретиків і практиків, які працюють у галузях державного управління й адміністративного процесу. Системний підхід до проблем адміністративного права дав змогу провести трунтовний аналіз атрибутивних ознак адміністративного права та процесу. У роботі також використані методи наукового пізнання, логічні методи аналізу, синтезу, узагальнення, порівняння, абстракиї.

На думку автора дослідження, аналіз будь-якої державно-правової проблеми, у тому числі проблеми адміністративного права та процесу, має здійснюватися на основі концепиії правової держави.

Основні результати дослідження. У сучасний період розвитку вірменської громади реалізація норм адміністративного права є одним із найактуальніших завдань державно-правової діяльності. Адміністративно-правові норми здійснюють вагомий вплив на суспільство загалом та на кожного громадянина Республіки Вірменія окремо через нормативно-правові акти ії органів, щзо стосуються забезпечення прав і законних інтересів громадян та господарюючих суб 'єктів у сфері публічного управління. Норми адміністративного права відіграють вагому роль у регулюванні, організації та функціонуванні державного апарату, забезпечуючи за допомогою адміністративних прочедур і регламентів належне та своєчасне визначення позитивних відносин у сфері державного управління. У зв'язку із цим автор акиентує увагу на ключових проблемах політико-правової модернізації та вдосконаленні адміністративного права й процесу Республіки Вірменія. Зокрема, розкриваються зміст та особливості предмета адміністративного права Республіки Вірменія, місие адміністративного права в системі публічного права, система й наука адміністративного права.

У результаті проведеної відповідно до поставленої мети дослідження роботи автор дійшов певних результатів і висновків, які, як видається, відображають основні тенденції в розвитку адміністративного права та процесу Республіки Вірменія, а також сприятимуть збагаченню, поповненню понятійного апарату науки адміністративного права й проиесу.

На науку адміністративного права істотний вплив чинять удосконалення та зміна вірменського законодавства, сочіально-економічні й політичні реформи, щчо проводяться в Республічі Вірменія, а також перетворення апарату управління.

На думку автора, сьогодні практично неможливо знайти сферу суспільних відносин, у якій не здійснюється адміністративно-правовий вплив.

У дослідженні приділено увагу також проблемам адміністративного процесу, адміністрування, законності, адміністративного правосуддя, співвідноменню адміністративного права й прочесу, адміністрування та актуальності проблем правозастосовної практики. Проведене дослідження дає змогу говорити про те, щзо спостерігається відхід від абсолютизачії нормативного підходу до адміністративного права, щзо переважав у радянській правовій науиі, плюралізм напряму в праворозумінні та інтеграція юридичних наук, у предмет яких включаються адміністративне право й прочес як об'єкти дослідження, зміни в змісті предмета, системи та структури адміністративного права й процесу.

Системний підхід до вивчення основних інститутів адміністративного права поглиблює наші уявлення про соиіальну природу адміністративного права й процесу, дає змогу глибше дослідити окремі інститути та категорії адміністративного права, ичілеспрямований розвиток ичивілізованого суспільства. 


\section{ЗАРУБІЖНЕ АДМІНІСТРАТИВНЕ ПРАВО ТА ПРОЦЕС}

У зв'язку зі змінами, щзо відбуваються в краӥні, змінюються також система й структура адміністративного права та прочесу, формальні джерела адміністративного права (наприклад, судовий та адміністративний прецедент).

Висновки. У дослідженні визначається вагомість формування адекватної філософсько-правової та світоглядної парадигми розвитку адміністративної правосвідомості, забезпечення правової стабілізачії вірменської громади в контексті модернізації політичної системи держави та заявленої реформи на основі ключових принципів сучасного демократичного права, поваги й захисту прав і свобод людини та громадянина.

Доктринальне розуміння адміністративної юриспрудениї знаходить нормативне закріплення, м'яко кажучи, у невідповідності. Це і є основною проблемою теорії адміністративного права, яка, на думку автора, може бути знята реформуванням законодавства (наприклад, з прийняттям нового Кодексу про адміністративні правопорушення тощоо).

Варто констатувати, що значимість адміністративного та адміністративно-процесуального законодавства, а також загалом норм адміністративного права привертає увагу вчених і фахівців-практиків. 3 огляду на наявну тенденцію розвитку юридичної науки можна стверджувати, що наука адміністративного права й надалі буде інтенсивно та перспективно розвиватися.

Ключові слова: правова держава, реформа, адміністративне право, адміністративний процес, модернізоване суспільство, система права, правопорядок, органи влади, громадянське суспільство, юриспруденція, політична система, права людини, адміністрування, адміністративний акт, правозастосовна практика, інтерпретація. 